\title{
SIFAT-SIFAT PENYALAAN BRIKET DENGAN MENGGUNAKAN SERBUK GERGAJIAN KAYU DENGAN COCO DUST SEBAGAI PEMANTIK
}

\section{IGNITION PROPERTIES OF BRIQUETTE MADE OF SAWDUST AND COCO DUST AS KINDLE MATERIAL}

\author{
Petrus Patandung \\ Balai Riset dan Standardisasi Industri Manado \\ Jalan Diponegoro No 21-23 \\ e-mail :patandungp@yahoo.com \\ Diterima tgl 28-05-2016, Disetujui tgl 17-06-2016
}

\begin{abstract}
ABSTRAK
Sifat-sifat serbuk gergajian kayu dengan coco dust untuk pembuatan briket telah dilaksanakan. Tujuan penelitian iniproduk briket yang diperoleh mudah dinyalahkan dengan menggunakan "coco dust"sebagai bahan pemantik atau penyalaan awal. Metode penelitian menggunakan bentuk gambar dan data dianalisis secara deskriptif. Hasil percobaan pembakaran briket dengan parameter: lama penyalaan sampai menjadi abu 98,63-100,65 menit; lama penyalaan awal sampai timbul api 0,04-0,09 menit dan asap yang ditimbulkan/asap yang hilang 10,15-18,13 menit. Untuk pendidihan air yang menggunakan arang briket serbuk gergajian kayu menggunakan waktu 20,30-24,68 menit dan menggunakan arang briket sebanyak 101,68-102,90 g. Briket arang serbuk gergajian kayu parameter kadar air 4,47-4,95\%, abu $5,14-7,03 \%$; bahan mudah menguappada suhu $950{ }^{\circ} \mathrm{C} 4,02-5,13 \%$ dan nilai kalori $2.220-3.862 \mathrm{cal} / \mathrm{g}$.
\end{abstract}

Kata Kunci: briket gergajian, coco dust, penyalaan.

\begin{abstract}
The research about many properties of wood sawdust with coco dust for making briquette has been implemented. The purpose of this research is to produce briquettes that iseasily ignited by using the "coco dust" as ignition material or startup. The research method uses a form of graphs and data were analyzed descriptively. Results of experiments with burning briquettes parameters: ignition time untilbriquettes bcame ashesranged from 98.63 to 100.65 minutes; period startup from 0.04 to 0.09 minutes until the resulting fire and smoke generated / smoke lost 10.15 to 18.13 minutes. For boiling water using wood sawdust charcoal briquettes took from 20.30 to 24.68 minutes and using charcoal briquettes as much as 101.68 to $102.90 \mathrm{~g}$. Charcoal briquettes of wood sawdust has moisture content from $4.47-4.95 \%$, ashes content from 5.14 to $7.03 \%$; volatile material at a temperature of $950{ }^{\circ} \mathrm{C}$ range from $4.02-5.13 \%$ and a calorific value of 2220-3862 cal / g.
\end{abstract}

Keywords: sawdust briquettes, coco dust, ignition

\section{PENDAHULUAN}

Kebutuhan kayu sebagai bahan

baku untuk berbagai keperluan terus meningkat sehingga pengolahan kayu memegang peranan penting dalam menentukan jenis-jenis produk bahan bangunan dari kayu yaitu berupa papan, balok, bingkai dan lain-lain. Dari pengolahan ini menghasilkan limbah industri yang berupa serbuk gergajian kayu dan belum diolah menjadi bahan lain atau kebutuhan industri dan hanya dibuang saja, padahal bahan tersebut merupakan selulosa yang dapat diolah menjadi bahan industri seperti untuk pengolahan briket.

Tanaman kelapa (Cocos Nucifera LINN) merupakan salah satu komoditas hasil pertanian yang penting peranannya bagi kehidupan manusia, karena seluruh 
bagiannya dapat diolah sedemikian rupa menjadi berbagai produk industri [1]. Pemanfaatan hasil tanaman kelapa di Sulawesi utara ini didominasi oleh daging buahnya sebagai protein nabati, airnya dibuat nata decoco, batangnya sebagai bahan bangunan dan lain sebagainya. Disamping itu bagian lainnya dapat dikembangkan seperti tempurung untuk pembuatan arang. Indonesia merupakan salah satu industri penghasil kelapa di dunia dengan produksi terbesar di daerah Sumatra, Jawa, Nusa Tenggara Barat dan Sulawesi.Sulawesi Utara merupakan sala satu daerah penghasil kelapa yang cukup potensial dengan data dari Dinas Perkebunan Provinsi Sulawesi Utara tahun 2013 adalah seluas $280.107 \mathrm{Ha}$ dengan produksi kopra 254.641 ton/tahun [2]. Di Sulawesi Utara sudah ada perusahan yang mengolah arang tempurung menjadi komoditi ekspor baik dalam bentuk arang aktif maupun dalam pengolahan arang tempurung yang berbentuk butiran-butiran "chips" dan menghasilkan limbah serbuk arang yang belum diolah menjadi bahan industri dan hanya dibuang saja sehingga menimbulkan dampak lingkungan disekitar pabrik tempurung kelapa. Pengolahan arang tempurung menjadi berbagai ukuran menghasilkan limbah arang sekitar 30\% yang sampai sekarang belum diolah menjadi bahan indutri, yang mana bahan tersebut masih mengandung nilai kalori yang cukup tinggi yaitu 5000-6000 kal/g. Di samping turunan kelapa tersebut dari pengolahan kopra diperoleh juga sabut kelapa dan serta coco dust yang belum diolah menjadi bahan industri dan hanya dibuang saja disekitar pengolahan sabut kelapa menjadi serat dan ahkirnya menimbulkan dampak lingkungan. Briket merupakan sumber energi cukup bagus untuk dikembangkan, karena bahan bakunya sangat berlimpah berasal dari kayu dan non kayu atau bahan-bahan limbah lainnya. Penggunaan briket salah satu kesulitan dalam penyalaan awal atau laju reaksi, karena briket tidak bisa menyala langsung bila tidak ada media penyulut/pemantik. Saat ini biasa digunakan minyak tanah dan solar yang bersifat berbau dan berasap, dan harganya mahal dan susah didapat, sehingga akan diteliti penggunaan bahan coco dust sebagai pemantik awal karena sifat dan karakteristik sangat mudah menyala dan terbakar yang berlangsung cepat.

Untuk menentukan mutu arang briket dapat digunakan Standar Mutu Arang Kayu dengan parameter: kadar air maksimum $8 \%$, bagian yang hilang pada pemanasan $950^{\circ} \mathrm{C}$ maksimum $15 \%$, abu maksimum $8 \%$ dan nilai kalori minimum $5000 \mathrm{kal} / \mathrm{g}$ sebagai pembanding [3]. Briket adalah arang yang diolah lebih lanjut menjadi bentuk briket (penampilan dankemasan yang lebih menarik) yang dapat digunakan untuk keperluan sehari-hari. Pembuatan briket dari limbah industri baik dari pengolahan kayu maupun dari tempurung dan pengolahan sabut menjadi serat-serat dapat menghasilkan limbah yang dapat diproses menjadi arang selanjutnya diolah menjadi bentuk briket dengan menggunakan bahan perekat seperti tepung tapioka, dimana bahan baku tersebut digiling atau ditumbuk kemudian dicampur dengan bahan perekat dengan menggunakan sistem hidrolik atau manual 
selanjutnya dikeringkan.Pembuatan arang briket dapat memberikan keuntungan antara lain dapat ditingkatkan kerapatannya sehingga volume menjadi kurang, bentuk dan ukurannya dapat disesuaikan dengan keperluan, tidak kotor, mudah diangkat, tidak memakan tempat pada waktu pengangkutan dan penyimpananserta nilai kalorinya cukup tinggi [4]. Pembuatan arang briket dapat memberikan keuntungan antara lain dapat ditingkatkan kerapatannya sehingga volume menjadi kurang, bentuk dan ukurannya dapat disesuaikan dengan keperluan, tidak kotor, mudah diangkat, tidak memakan tempat pada waktu pengangkutan dan penyimpananserta nilai kalorinya cukup tinggi. Arang serbuk sabut kelapa mengandung kadar air 3,50\%, abu $4,40 \%$, bahan mudah menguap pada suhu $950^{\circ} \mathrm{C} 12,56 \%$ dan karbon terikat $79,50 \%$ [5] dan briket limbah arang tempurung kelapa mengandung kadar air 4,50\%, abu $6,73 \%$, bagian yang hilang pada pemanasan $950^{\circ} \mathrm{C} 13,75 \%$ dan nilai kalori $6736,5 \mathrm{kal} / \mathrm{g}$. Mutu briket dapat dibandingkan dengan beberapa bahan baku antara lain; batubara 4500-7500 kal/g, kokos 6000-7000 kal/g dan briket arang kayu 4000-6000kal/g [6]. Peralatan dan mesin pembriketan dapat digolongkan sebagai berikut: sistem mekanis tidak kontinyu, sistem hidrolik tidak kontinyu, sistem ekstruksi kontinyu dan sistem rollpress kontinyu [7]. Proses pembuatan briket dapat melalui beberapa tahap:penghancuran/penghalusan yaitu bahan baku digiling sampai halus kemudian diayak dengan menggunakan ayakan yang berukuran $2 \times 2 \mathrm{~mm}$ sehingga diperoleh bahan baku yang lolos ayakan tersebut dan digunakan sebagai bahan dasar pembuatan briket.

Bahan baku dicampur dengan perekat dan bahan-bahan lain agar dapat dicetak, bahan perekat yang digunakan adalah kanji dan tambahanperekat lainnya seperti bentonit dengan perbandingan tertentu kemudian dicampur sampai homogen lalu ditambahkan bahan baku lain seperti $\mathrm{KNO}_{3}$, dengan perbandingan 92,5: 2,5: 2,0. Pencetakan adonan yang telah dicampur dicetak dengan menggunakan cetakan Screw press daya tekan $60-600 \mathrm{~kg} / \mathrm{cm}^{2}$, dengan demikian tekanan dapat diatur sehingga kepadatan briket dapat memenuhi standar mutu [8].Untuk menilai briket digunakan pembanding buatan Inggris, Jepang dan syarat mutu arang kayu. Buatan Inggris: kadar air 3,59\%, Abu $8,26 \%$, nialai kalori $7289 \mathrm{kal} / \mathrm{g}$ dan kerapatan jenis $0,84 \mathrm{~g} / \mathrm{cm}^{3}$. Buatan jepang: kadar air 6,0\%, abu 3-6\%, nilai kalori 60007000kal/g.SNI 01-6235-2000; persyaratan mutu briket arang kayu: kadar air max. $8 \%$, abu max. $8 \%$, bagian hilang pada pemanasan $950^{\circ} \mathrm{C}$ max. $15 \%$ dan nilai kalori $5000 \mathrm{kal} / \mathrm{g}$.Tujuan penambahan bahan perekat adalah untuk memasukkan atau menarik air dan membentuk tektur yang padat atau menggabungkan antara dua atau lebih substrat yang direkat. Pemilihan dan penggunaan bahan perekat dilakukan dengan beberapa hal antara lain mempunyai daya serap yang baik terhadap air dan harganya relatif murah serta mudah didapat. Kekuatan perekat dipengaruhi oleh sifat briket, alat dan teknik perekatan yang digunakan, pematangan perekat akan terjadi dan menghasilkan keteguhan rekat yang baik disertai dengan tekanan yang 
cukup. Pemberian tekanan antara lain dimaksudkan untuk meratakan perekat dan untuk memasukkan perekat kedalam poripori [9]. Ditinjau dari macam bahan perekat yang digunakan, produk yang dihasilkan dapat dibedakan antara arang briket yang tidak atau kurang berasap dan banyak berasap. Pemakaian ter, pitch dan molase sebagai bahan perekat menghasilkan briketyang tinggi kekuatannya, tetapi memberikan asap jika dibakar. Oleh karena itu bahan perekat tersebut kurang cocok untuk membuat briket yang digunakan sebagai bahan bakar dalam rumah tangga. Bahan perekat dari zat pati, dekstrin dan tepung beras akan menghasilkan arang briket yang tidak berasap dan tahan lama, tetapi nilai kalorinya tidak terlalu tinggi [10].Tujuan penelitian ini untuk mengetahui sifat-sifat penyalaan briket serbuk gergajian kayu dengancocodust sebagai bahan pemantik untuk briket.

\section{BAHAN DAN METODE}

\section{Bahan dan Alat}

- Bahan yang digunakan yaitu limbah, arang serbuk gergajian kayu dan limbah coco dust.

- Alat yang digunakan yaitu drum pembakaran serbuk gergajian kayu dan limbah coco dust, kompor, loyang plastik, pengaduk,alat pencampur, alat pengering dan alat cetak briket.

\section{Metode Penelitian}

\section{Persiapan bahan baku}

Metode penelitian melalui 2 (dua) tahap penelitian yaitu pembuatan arang dari serbuk gergajian kayu yang menggunakan metode drum dengan pembakaran bertahap. Arang yang diperoleh digiling dan diayak lewat ayakan 10 mesh kemudian dijadikan bahan baku untuk pembuatan briket.

\section{Metode PenelitianPembuatan Briket.}

Penyajian data penelitian ini menggunakan metode Gambar/Grafik dan data dianalisis secara deskriptif. Percobaan dilakukandengan melalui pembuatan briket yang menggunakan bahan perekat kanji 5 g, dengan kehalusan coco dust lolos ayakan 10 mesh sebanyak $50 \mathrm{~g}$ yang merupakan konstan, dengan perlakuan yang terdiri dari:A1=100 g limbah serbuk arang kayu ditambah $50 \mathrm{~g}$ coco dust; A2 $=200 \mathrm{~g}$ limbah serbuk arang kayu ditambah $50 \mathrm{~g}$ coco dust; $\mathrm{A} 3=300 \mathrm{~g}$ limbah serbuk arang kayu ditambah $50 \mathrm{~g}$ coco dust; $\mathrm{A} 4=400 \mathrm{~g}$ limbah serbuk arang kayu ditambah $50 \mathrm{~g}$ coco dust.Penelitian diulang 2 (dua) kali.

\section{Pembuatan Briket}

Limbah arang serbuk gergajian kayu ditimbang sesuai perlakuan dengan menggunakan bahan perekat kanji $5 \%$. Bahan perekat yang digunakan dilarutkan dengan air dingin terlebih dahulu kemudian ditambahkan air panas dan dimasak selama 10-15 menit sehingga membentuk pasta atau cairan pekat lengket lalu bahan tersebut dicampur sampai homogen dan adonan dicetak dengan menggunakan pipa besi diameter $5 \mathrm{~cm}$ dan tinggi $4 \mathrm{~cm}$ kemudian produk briket dikeringkan sinar matahari.

\section{Parameter yang dianalisis}

Parameter yang dianalisis yaitu kadar air, abu, bahan yang mudah menguap pada suhu $950^{\circ} \mathrm{C}$ dan karbon terikat (SNI Briket 
Arang Kayu 01-6235-2000) sebagai pembanding dan juga dilakukan pengujian: lama penyalaan sampai menjadi abu, lama penyalaan awal sampai timbul api, asap yang ditimbulkan dan lama asap hilang.

\section{HASIL DAN PEMBAHASAN}

\section{Pengujian Laboratorium}

Hasil pengujian laboratorium produk briket limbah arang serbuk gergajian kayu dengan menggunakan coco dust sebagai bahan pemantik dan uji coba pembakaran briket dapat dilihat pada Gambar 1, 2,4, 5, 6, 7 dan 8.

\section{Lama Penyalaan Sampai Menjadi Abu}

Hasil analisis uji coba pembakaran briket (Gambar 1) menunjukkan hasil pembakaran briket arang serbuk gergajian lama penyalaan sampai menjadi abu, hasil yang tertinggi diperoleh pada perlakuan A4 dengan menggunakan arang serbuk gergajian $400 \mathrm{~g}$ dan coco dust $50 \mathrm{~g}$ yaitu sebesar 100,65 menit dan yang terendah diperoleh pada perlakuan A1 dengan menggunakan arang serbuk gergajian kayu $100 \mathrm{~g}$ dan coco dust $50 \mathrm{~g}$ yaitu sebesar 98,63 menit.

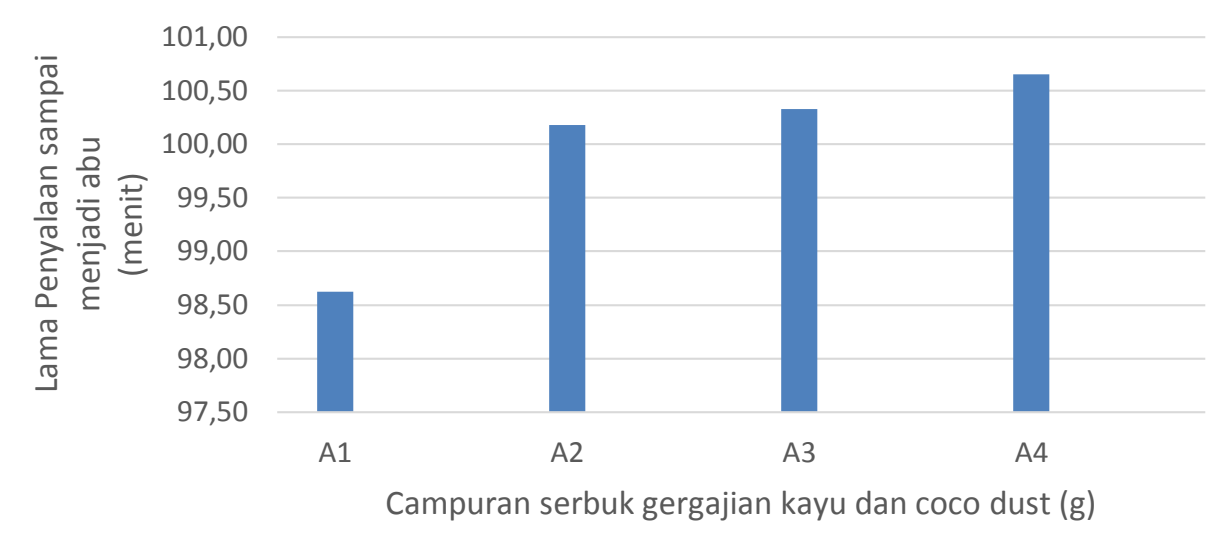

Gambar 1. Hubungan antara campuran serbuk gergajian kayu dan coco dust (g) terhadap lama penyalaan sampai menjadi abu (menit)

Tinggi rendahnya lama penyalaan sampai menjadi abu disebabkan karena ukuran partikel dari serbuk limbah arang serbuk gergajian kayu yang lebih halus sehingga kepadatan lebih rapat yang mengakibatkan rongga atau sirkulasi udara tidak merata kepermukaan briket dan juga arang serbuk gergajian semakin tinggi lama penyalaan briket sampai menjadi abu hal ini disebabkan karena partikel-partikel serbuk gergajian yang ringan serta kadar air yang cukup rendah sehingga proses pembakaran lebih cepat [11].

\section{Lama Penyalaan sampai Timbul Api}

Hasil analisis atau uji coba pembakaran briket dengan menggunakan arang serbuk gergajian kayu (Gambar 2) menunjukkan bahwa hasil yang tertinggi diperoleh pada perlakuan A4 dengan menggunakan arang serbuk gergajian kayu $400 \mathrm{~g}$ dan coco dust $50 \mathrm{~g}$ yaitu sebesar 0,09 menit dan yang terendah diperoleh pada perlakuan A1 dengan menggunakan arang serbuk gergajian kayu $100 \mathrm{~g}$ dan coco dust $50 \mathrm{~g}$ yaitu sebesar 0,04 menit. 


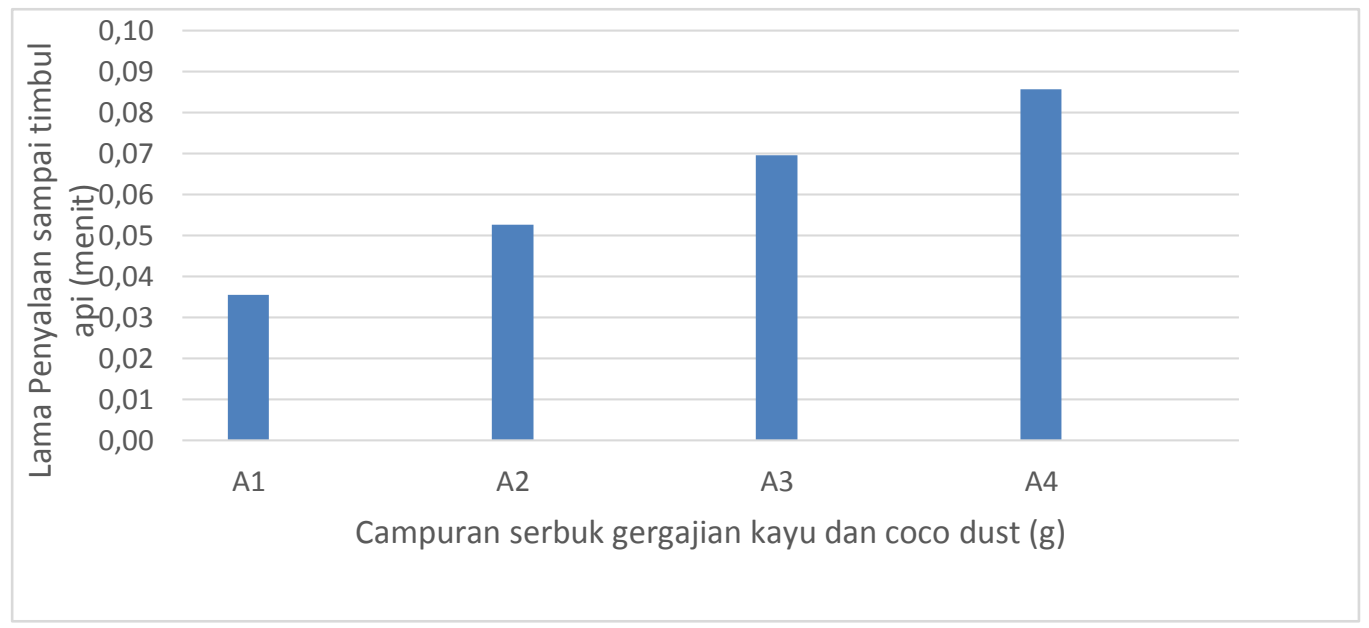

Gambar 2. Hubungan antara campuran serbuk gergajian kayu dan coco dust (g) terhadap lama penyalaan sampai timbul api (menit)

Tinggi dan rendahnya hasil yang diperoleh disebabkan oleh kandungan air yang terdapat di dalam briket yaitu semakin tinggi kadar air semakin lama proses penyalaan dan semakin rendah kadar air semakin cepat proses penyalaan sampai timbul api.

\section{Asap Yang Timbul/ Lama Asap Hilang.}

Hasil analisis uji coba pembakaran briket yang menggunakan limbah arang serbuk gergajian (Gambar3) menunjukkan hasil yang tertinggi diperoleh pada perlakuan A4 dengan menggunakan arang serbuk gergajian $400 \mathrm{~g}$ dan coco dust $50 \mathrm{~g}$ yaitu sebesar 18,13 menit serta yang terendah diperoleh pada perlakuan A1 dengan menggunakan arang serbuk gergajian kayu $100 \mathrm{~g}$ dan coco dust $50 \mathrm{~g}$ yaitu sebesar 10,15 menit.

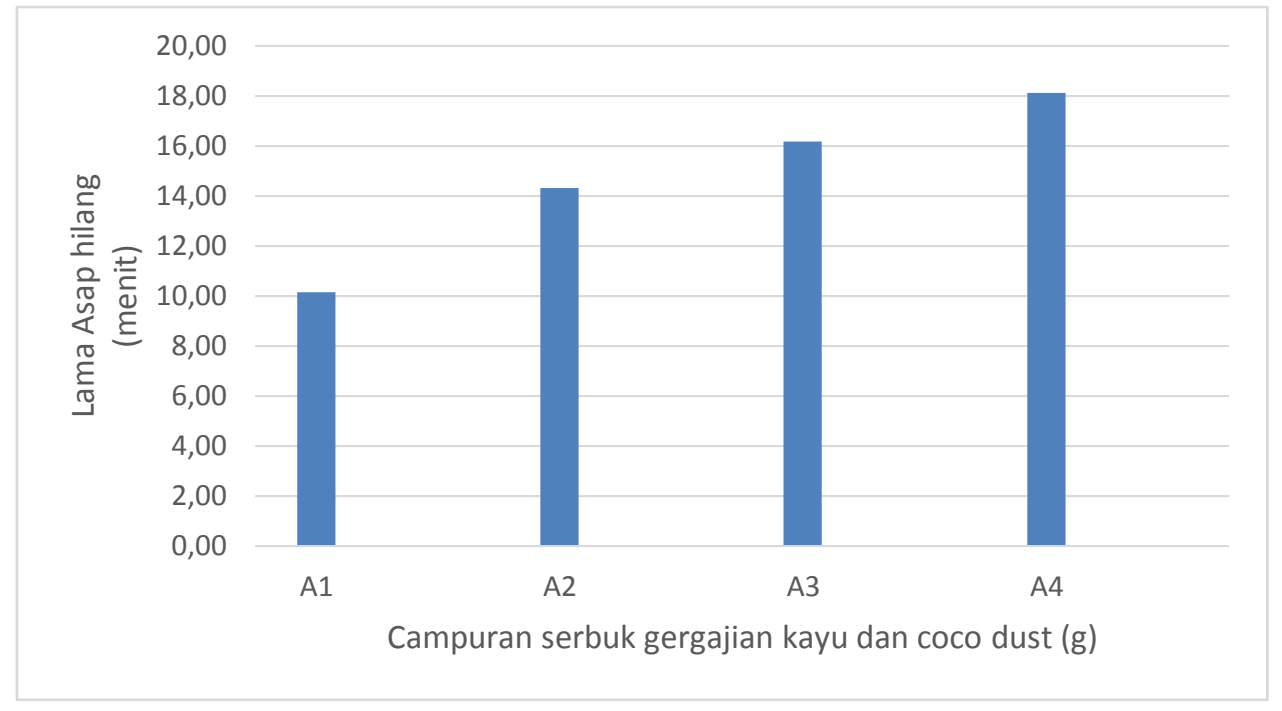

Gambar 3. Hubungan antara campuran serbuk gergajian kayu dan coco dust (g) terhadap lama asap hilang (menit) 
Tinggi dan rendahnya hasil yang diperoleh karena disebabkan oleh adanya komposisi biomassa dan kadar air yang dikandung oleh briket.

\section{Lama Pendidihan Air}

Hasil uji coba pendidihan air (Gambar 4) pembakaran briket yang menggunakan arang serbuk gergajian kayu menunjukkan bahwa hasil pendidihan yang tertinggi diperoleh pada perlakuan A4 dengan menggunakan arang serbuk gergajian 400 $\mathrm{g}$ dan coco dust $50 \mathrm{~g}$ yaitu sebesar 24,68 menit dan yang terendah diperoleh pada perlakuan $\mathrm{A} 1$ dengan menggunakan arang serbuk gergajian kayu $100 \mathrm{~g}$ dan coco dust $50 \mathrm{~g}$ yaitu sebesar 20,30 menit.

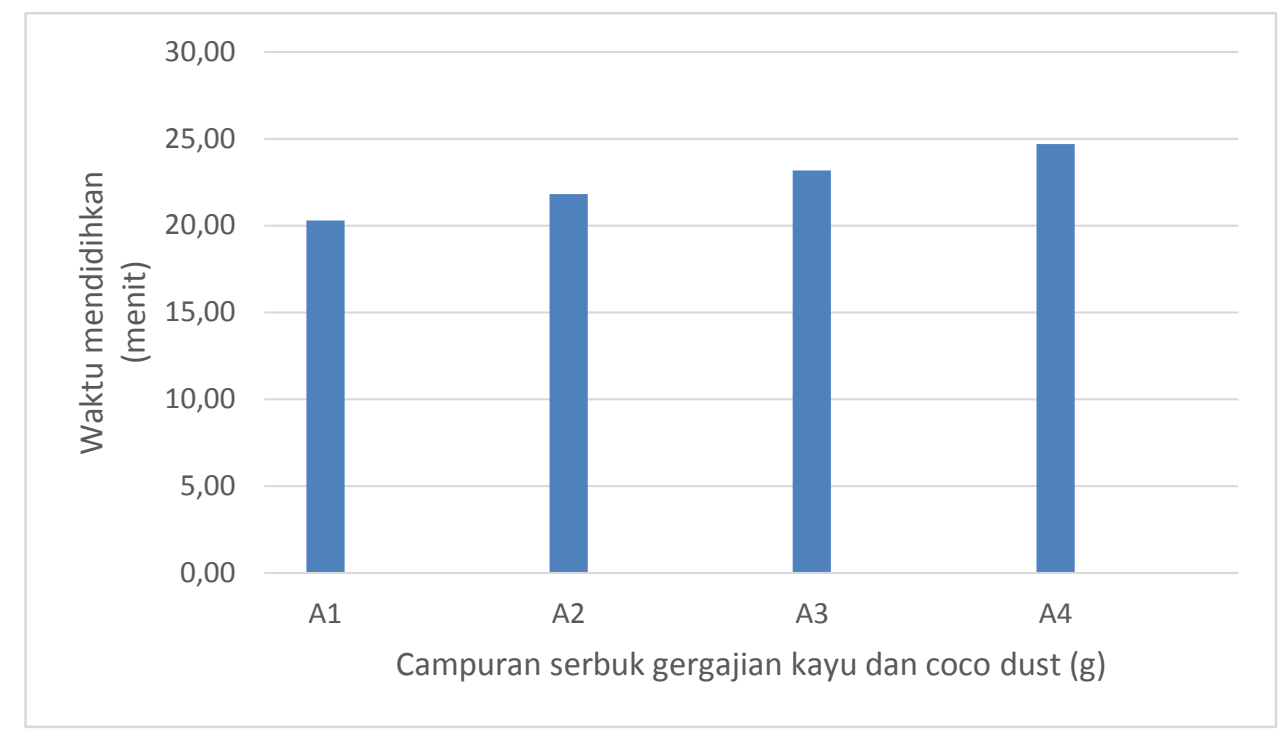

Gambar 4. Hubungan antara campuran serbuk gergajian kayu dan coco dust (g) terhadap lama waktu menddidihkan air (menit)

Hasil pendidihan air mengalami kenaikan dari limbah briket serbuk gergajian kayu dipengaruhi oleh kadar air yaitu semakin tinggi kadar air proses pembakaran mengalami waktu yang lama dan sebaliknya briket yang mengandung kadar air rendah proses pembakaran mengalami waktu yang relatif singkat.
Air

Hasil analisis produk briket dengan menggunakan arang serbuk gergajian(Gambar5) menunjukan bahwa hasil yang tertinggi diperoleh pada perlakuan A4 dengan menggunakan arang serbuk gergajian $400 \mathrm{~g}$ dan coco dust $50 \mathrm{~g}$ yaitu sebesar $4,95 \%$ serta yang terendah diperoleh pada perlakuan A1 dengan menggunakan arang serbuk gergajian 100 $\mathrm{g}$ dan coco dust $50 \mathrm{~g}$ yaitu sebesar $4,47 \%$. 


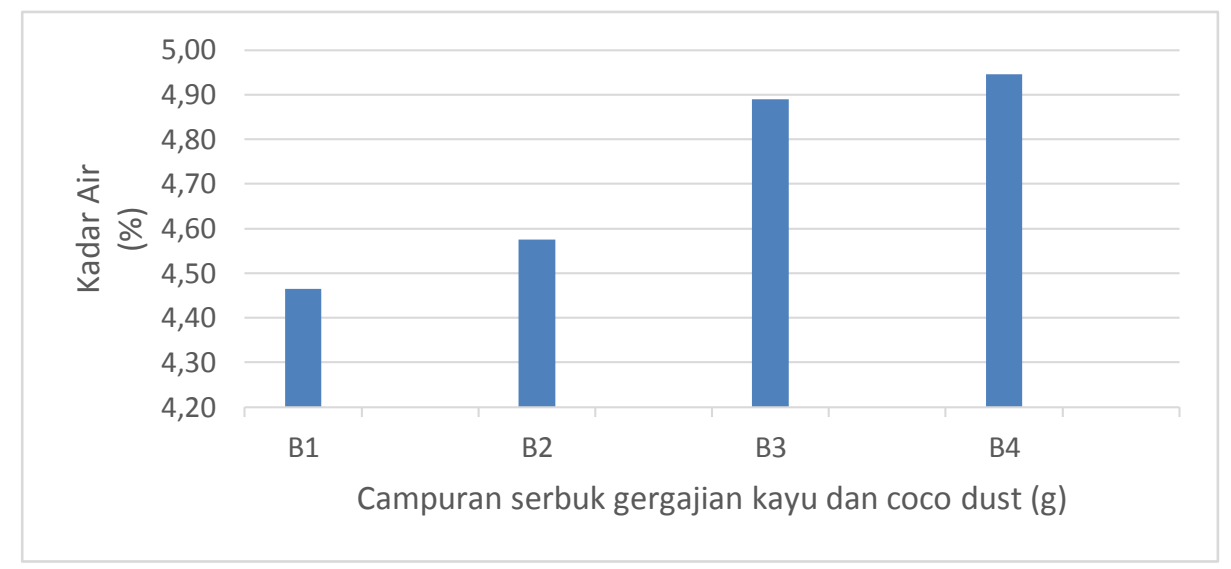

Gambar 5. Hubungan antara campuran serbuk gergajian kayu dan coco dust (g) terhadap Kadar air (\%)

Tinggi dan rendahnya hasil yang diperoleh disebabkan karena bahan baku yang cukup mengandung kadar air yang tinggi dan juga dipengaruhi oleh proses pengeringan.

\section{Abu}

Hasil analisis produk briket dengan menggunakan arang serbuk gergajian (Gambar 6) menunjukkan bahwa hasil yang tertinggi diperoleh pada perlakuan A4 dengan menggunkan arang serbuk gergajian $400 \mathrm{~g}$ dan coco dust $50 \mathrm{~g}$ yaitu sebesar $7,03 \%$ dan yang terendah diperoleh pada perlakuan A3 dengan menggunakan arang serbuk gergajian 300 g dan coco dust 50 yaitu sebesar 5,15\%. Jika dibandingkan dengan standar briket arang kayu masih memenuhi syarat mutu.

Tinggi dan rendahnya hasil abu yang diperoleh disebabkan karena adanya penambahan serbuk limbah arang serbuk gergajian yang mana semakin tinggi penambahan limbah serbuk gergajian kayu semakin tinggi abu yang dihasikan dan sebaliknya semakin rendah penambahan serbuk limbah arang serbuk gergajian kayu semakin rendah kadar abu [12].

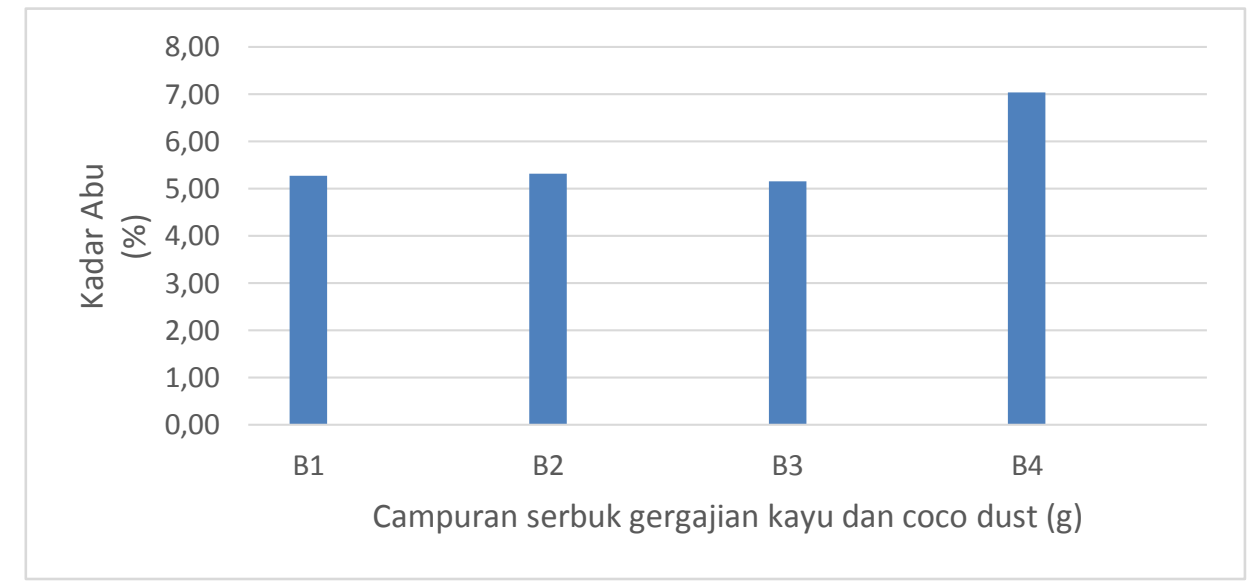

Gambar 6. Hubungan antara campuran serbuk gergajian kayu dan coco dust (g) terhadap Kadar abu (\%) 


\section{Bahan Mudah Menguapa Pada Suhu 950} ${ }^{\circ} \mathrm{C}$.

Hasil analisis briket arang serbuk gergajian (Gambar 7) menunjukkan bahwa hasil yang tertinggi diperoleh pada perlakuan A4 dengan menggunakan arang serbuk gergajian $400 \mathrm{~g}$ dan coco dust $50 \mathrm{~g}$ yaitu sebesar $5,13 \%$ dan yang terendah diperoleh pada perlakuan A1 dengan menggunakan serbuk arang gergajian 100 $\mathrm{g}$ dan coco dust $50 \mathrm{~g}$ yaitu sebesar $4,02 \%$. Jika dibandingkan dengan standar briket arang kayu masih memenuhi syarat mutu.

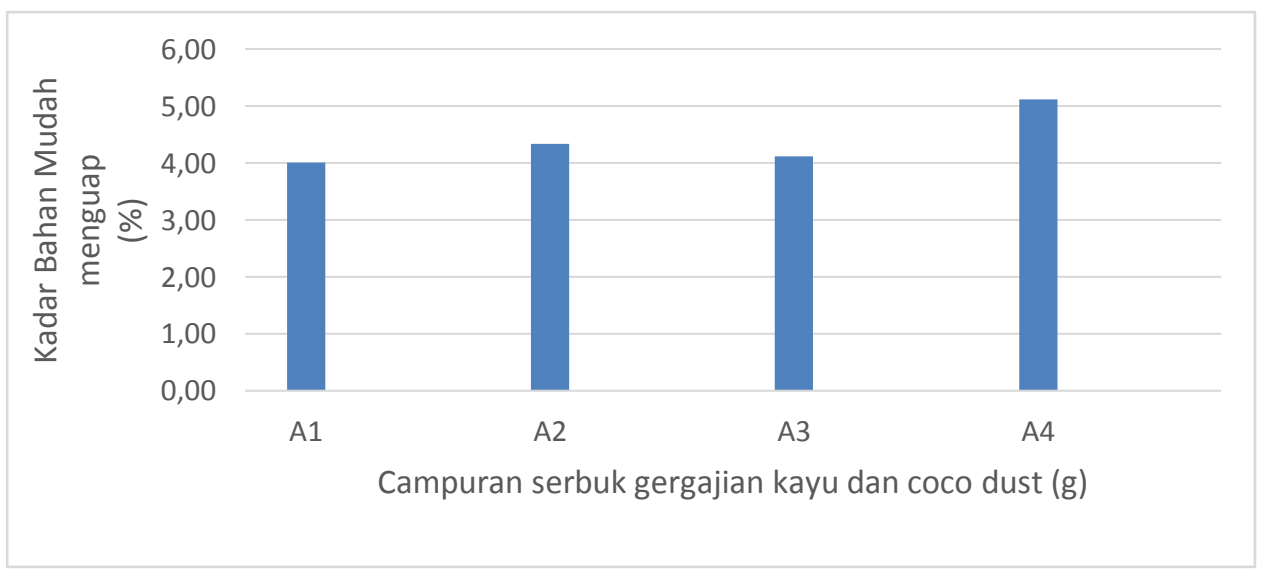

Gambar 7. Hubungan antara campuran serbuk gergajian kayu dan coco dust (g) terhadap Kadar Bahan Mudah Menguap (\%)

Tinggi dan rendahnya hasil yang diperoleh disebabkan karena pengaruh dari kadar abu yang dihasilkan yang semakin tinggi kadar abu semakin tinggi juga kadar bahan menguap sebaliknya semakin rendah kadar abu yang diperoleh menyebabkan bahan mudah menguap lebih rendah.

\section{Nilai Kalori}

Hasil analisis produk briket dengan menggunakan arang serbuk gergajian kayu
(Gambar 8)menunjukkan bahwa hasil yang tertinggi diperoleh pada perlakuan A1 dengan menggunakan arang serbuk gergajian $100 \mathrm{~g}$ dan coco dust $50 \mathrm{~g}$ yaitu sebesar $3.862 \mathrm{cal} / \mathrm{g}$ dan yang terendah diperoleh pada perlakuan A4 dengan menggunakan arang serbuk gergajian 400 g dan coco dust $50 \mathrm{~g}$ yaitu sebesar 2220 $\mathrm{cal} / \mathrm{g}$.

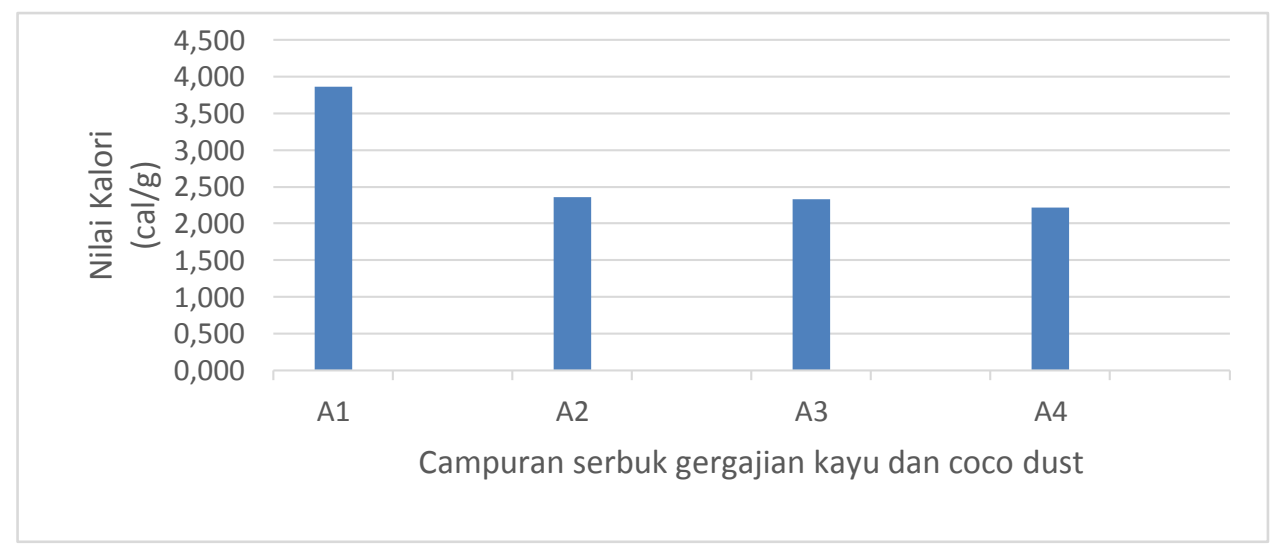

Gambar 8. Hubungan antara campuran serbuk gergajian kayu dan coco dust (g) terhadap Nilai Kalori (cal/g) 
Jika dibandingkan dengan standar briket arang kayu belum memenuhi syarat mutu. Tinggi dan rendahnya nilai kalori yang diperoeh disebabkan oleh bahan baku limbah arang serbuk gergajian kayu yang mengandung nilai kalori yang rendah.

\section{KESIMPULAN}

Hasil percobaan menunjukkan bahwa coco dust dapat digunakan sebagai bahan pemantik atau bahan penyalaan awal dari pembakaran briket limbah arang serbuk gergajian kayu. Hasil percobaan pembakaran arang briket serbuk gergajian kayu menunjukkan bahwa parameter lama penyalaan sampai menjadi abu 98,63100,65 menit; lama penyalaan awal sampai menjadi sampai timbul api 0,04-0,09 menit dan asap yang ditimbulkan/asap yang hilang 10,15-18,13 menit.sedangkan untuk pendidihan air yang menggunakan arang briket serbuk gergajian menggunakan waktu 20,30-24,68 menit dan menggunakan arang briket sebanyak $101,68-102,90$ g. Briket arang serbuk gergajian parameter kadar air 4,47-4,95\%, abu 5,14-7,03\%; bahan mudah menguappada suhu $950{ }^{\circ} \mathrm{C}$ 4,02-5,13\% dan nilai kalori 2.220-3.608 cal/g.

\section{DAFTAR PUSTAKA}

1. Tonga. Coconut steam utilization seminar. Ministry of Foreign Affairs. New Zealand: Wellington; 1979.

2. Sulawesi Utara dalam Angka. Potensi tanaman kelapa di Provinsi Sulawesi Utara. Manado;2013.

3. Dewan Standar Nasional Indonesia. Syarat mutu arang kayu. SNI 01-6235-2000.Jakarta: Kementrian Perindustrian; 2000.
4. Supriyanto. 2008. Peningkatan kualitas briket untuk tungku rumah tangga. Bandung:Pusat Penelitian Fisika LIPI; 2008.

5. Patandung $\mathrm{P}$, Pojoh $\mathrm{B}$, Lohoo $\mathrm{F}$, Tambuwun TR, Saselah O, Hartanto D, Welly $R$ dan Mamahani GF. Penelitian pemanfaatan serbuk sabut kelapa untuk arang. Manado: Balai Penelitian dan Pengembangan Industri Manado;1993

6. Sudrajad R. Mesin briket ukuran partikel granular. CrusherProcess.Com. Diakses tanggal 28 Juli 2013,

7. Apandi TT. Rancang bangun mesin pembriketan batu bara di Tegal, Jawa Tengah. Jakarta: Departemen Energi dan Sumber Daya Mineral RI; 1995.

8. Amin S. Penelitian berbagai jenis kayu limbah pengolahan untuk pemilihan bahan baku briket arang.Jurnal Sains dan Teknologi Indonesia 2. 2000. (2) 41-46.

9. Hendra DJ. Teknologi tepat guna pembuatan arang briket dan tungku hemat energi. Bogor: Puslitbang Hasil Hutan;2007.

10. Syamsiro M dan Saptoadi H. Pembakaran briket biomassa cangkang kakao: Pengaruh temperatur udara preheat. Yogyakarta: Seminar Nasional Teknologi; 2007.

11. Jamilatun S. Sifat-sifat penyalaan dan pembakaran briket biomassa, briket batubara dan arang kayu. Jurnal Rekayasa Proses. 2012 May 1;2(2):37-40.

12. Aprianti. Pemanfaatan sampah organik sebagai briket, ITS Surabaya, Jurusan Teknik Kimia. Surabaya; 2008. 